\section{Reactional state and nutritional profile among leprosy patients in the primary health care system, Greater Vitória, Espírito Santo State, Brazil}

\author{
Estado reacional e perfil nutricional em portadores \\ de hanseníase acompanhados na rede de atenção \\ primária à saúde da Grande Vitória, Espírito Santo, \\ Brasil
}

\author{
1 Universidade Federal do \\ Espírito Santo, Vitória, Brasil. \\ Correspondence \\ R. M. N. Montenegro \\ Universidade Federal do \\ Espírito Santo. \\ Rua Doutor Dido Fontes 40 \\ apto. 201, Vitória, ES \\ 29060-280, Brasil. \\ rnnegro@hotmail.com
}

\begin{abstract}
Leprosy may present acute/subacute inflammatory processes (leprosy reactions). The study characterized the reactional states of patients at health clinics in Vitória, Espirito Santo State, Brazil, and associated them with sociodemographic factors and clinical/nutritional variables. between January and December 2009, longitudinal follow-up of patients with leprosy continued until leprosy reactions occurred or patients completed 6 months of multidrug therapy. Of the 151 patients participating, 78 (51.7\%) were females, 48 (31.8\%) had 5 to 8 years schooling, 93 (61.6\%) worked and earned from 1 to 3 minimum wages, and 55 (36.4\%) had leprosy reactions, but with no statistical association to socioeconomic characteristics or nutritional status. However, absence of reaction was more common in the low-weight group, suggesting a trend in this group to protection from the reaction $(p=0.0906)$. The study found no association between nutritional status and leprosy reaction.
\end{abstract}

Leprosy; Nutrition Surveys; Body Mass Index
Rosa Maria Natalli Montenegro 1

Eliana Zandonade 1

Maria Del Carmen Bisi Molina 1

Lúcia Martins Diniz 1

\section{Introduction}

Leprosy is an infectious disease whose evolution is chronic, caused by the bacillus Mycobacterium leprae or Hansen's bacillus, which is highly infectious, but only weakly pathogenic 1 .

During treatment for leprosy, and in other circumstances, certain reactions may occur. What are known as leprosy reactions or reactional states are acute or sub-acute conditions, normally interspersed irregularly in the silent, chronic course of the evolution of leprosy's chronic evolution. They may be (a) type I or reversal reactions or (b) type II reactions 2,3,4,5,6.

Although it is recognized that leprosy reactions are implicated in generating disabilities 7 and affect patients' quality of life - they lead to pain, deformities and absenteeism ${ }^{6}$ - studies that identify risk situations for the occurrence of these problems are scarce. Studies have demonstrated reaction frequencies ranging from $20 \%$ to $69.9 \%$ in patients with leprosy, the variation stemming from the different clinical forms of the disease $6,8,9$.

The scientific literature points to a number of factors that will trigger reactional states, such as: infections (malaria, filariasis, septicemias, typhoid fever, influenza, dental abscess, tonsillitis), physical or psychological stress, ingestion of products containing iodides, and probably bromides, even in small quantities, highly spiced food or alcohol in excess, physiological condi- 
tions such as menstruation and pregnancy, vaccination against smallpox, typhoid fever, PPD test, lepromin test, anti-leprosy drugs such as chaulmoogra oil and sulfones 6 .

Nutrition and its importance in preventing disease and promoting health are the subject of much discussion today. The health promotion field is discussing the possibility of generating "health reserves", as another resource for living longer and with better quality of life, by cultivating a healthier lifestyle that includes being more careful about diet, among other things 10 . In this way, nutrition is gaining importance both as a therapeutic resource in hospital treatment (for disease prevention and control) and also in promoting health and quality of life. Accordingly, personnel whose work involves promoting health, preventing disease and restoring health should understand the nutrition process as a physiological phenomenon directly influenced by environmental, social and psychological conditions 10 .

Some studies address socio-demographic conditions and nutritional profile as important factors in caring for patients with leprosy 11,12,13. The authors of one study in India in 200014 conclude that the food insecurity and low socioeconomic status that favor malnutrition are associated with the appearance of the physical disabilities of the disease and with the nutritional status of the family members. One study of the stigma caused by leprosy observes that loss of employment and declining standard of living affect overall health and quality of life 15. Accordingly, this present study aims to characterize the reactional states of patients treated at primary health care centers in Greater Vitória, Espírito Santo State, and to identify the socio-demographic factors, and clinical and nutritional variables involved in, and their correlations with, the appearance of leprosy reactions.

\section{Material and methods}

A longitudinal, follow-up study was made of new cases of leprosy diagnosed from January to December 2009. These patients or monitored until a leprosy reaction appeared or to at least six months after starting multiple drug therapy. Although leprosy reactions can occur up to 5 years after starting treatment, $20 \%$ to $30 \% 16$ of cases occur in the first 6 months (the period covered by our study). That fact is a limitation on outcome analysis, and will be discussed below.

Patients diagnosed as co-infected with tuberculosis, those knowingly with acquired immunodeficiency syndrome, and those with lep- rosy reactions and physical disabilities caused by the disease at the time of diagnosis, were excluded, because these could trigger systemic alterations, impairing patient nutritional assessment. Endocrine-metabolic comorbidities were not evaluated.

The sample size was calculated with Epidat, version 3.1 (Xunta de Galicia, Spain; http://dxsp. sergas.es/default.asp), using the sample size formula to estimate proportion (proportion of leprosy reactions). Population data on patients with leprosy in the municipalities of Vitória, Vila Velha, Serra and Cariacica in 2007 were used, a total of 400 new cases 17 , with a reaction incidence of approximately $20 \%{ }^{6}$. The desired precision was considered to be $5.5 \%$ and the level of significance, $5 \%$. The minimum sample size returned was 135 patients.

Data were collected at a primary health clinics in the municipalities of Vitória, Vila Velha, Serra and Cariacica at the time of the first appointment after confirmation of the diagnosis. These municipalities were studied because they group the largest number of patients on active record, and are located in the Greater Vitória metropolitan region.

Socio-demographic data were obtained through scripted interviews. Data on the disease were obtained from patient clinical records, and transcribed to the collection instrument. The medical records contained all the leprosy-related variables used in this study, and were properly completed.

The Madrid classification used in this study defines the concept of polar forms of leprosy, where patients evolve from the indeterminate (IL) form to the tuberculoid (TL) form, if they are resistant, or to the Virchowian (VL) or lepromatous (LL) form, if the bacillus multiplies. The interpolar group of patients are denominated borderline or dimorphous, because they present clinical aspects of the $\mathrm{T}$ and $\mathrm{V}$ polar forms, that is, their clinical condition falls between the two forms of the disease ${ }^{3}$.

The operational classification criteria used here were those put forward by the World Health Organization: paucibacillary (PB) leprosy for patients with a single lesion, and two to five lesions; and multibacillary (MB) leprosy for patients with more than five lesions 8 .

For anthropometric evaluation, weight (W) and height $(\mathrm{H})$ were measured. Weight was determined using a beam scales, calibrated as determined by Brazil's National Standards Institute (Instituto Nacional de Metrologia - INMETRO). The approximate weight of clothing was subtracted from the measured weight, and the scales were tared at each weighing. 
Height was measured using a fixed rod stadiometer attached to the scales. With the patients barefoot, their weight evenly distributed between their feet, arms extended beside their body and heels together touching the vertical rod of the stadiometer, the headpiece was lowered until it touched the highest point of their head.

Body mass index (BMI) or Quetelet index is a simple weight-to-height index used to classify nutritional state. It is calculated by dividing weight in kilograms (kg) by height in meters (m) squared $\left[\mathrm{BMI}=\right.$ weight $(\mathrm{kg}) /$ height $\left.\left(\mathrm{m}^{2}\right)\right]$. The WHO classification was used to evaluate nutritional state of adolescents, adults and the elderly 18 .

Skinfold measurements were taken using an appropriately calibrated, Lange adipometer, with patients standing, arms hanging loosely by their sides. Measurements were taken directly from patient skin, and total body fat was measured without any substances that might influence pinching of the skinfold. As a standard, measurements were taken on the right side, in keeping with universally established criteria. These measurements were analyzed in isolation, by applying the percentile table and were interpreted following Frisancho 19.

Arm circumference (AC) comprises the sum of the areas constituted by the arm's bone, muscle and fatty tissue. This measurement was taken with patients standing, arms relaxed by their sides and palms turned inwards, following the universally established technique for AC. The value found was compared with AC percentile values by age and sex 19 .

The other measurement used was arm muscle circumference (AMC), which evaluates the muscle tissue reserve, with no correction for bone area. This was obtained from the AC and triceps skinfold thickness (TST) values, and was interpreted following Frisancho 19.

Data were presented descriptively by statistical analysis using SPSS, version 17.0 (SPSS Inc., Chicago, USA). Absolute and percentage frequencies were calculated for the qualitative variables, and means and standard deviations for the quantitative variables. The association between leprosy reaction and the demographic and leprosyrelated variables and nutritional state were determined by chi-square test. The level of significance used was $5 \%$.

The study was submitted to, and approved by, the ethics committee of the Universidade Federal do Espírito Santo, under process no. 013/09. The ethical requirements for research with human subjects were met, and the information collected was kept confidential.

\section{Results}

During the study period, 151 patients participated, 78 (51.7\%) of them female. Age ranged from 10 to 74 years, and the disease was homogeneously distributed by age group, with a slight increase among the 40 to 49 year olds (29 patients; $19.2 \%$ ). Forty-eight (31.8\%) of the participants had from 5 to 8 years schooling. Ninety-three (61.6\%) had formal employment, with wage earnings of up to three minimum wages. Fifty-five (36.4\%) presented leprosy reaction by the closing date stipulated for follow-up.

No statistically significant association was found between the socio-economic characteristics and the presence of leprosy reaction (Table 1).

A statistical association was observed between the clinical form and the frequency of reactions, as shown in Table 2 . In the group with reaction, leprosy most often took the dimorphous form, followed by the tuberculoid and Virchowian forms, whilst in the group with no reaction the tuberculoid form was most frequent $(p=0.0106)$. Also, reactions were more frequent in individuals with positive smear test, and these were statistically significant ( $\mathrm{p}=0.0378$ ).

The nutritional state of the patients studied is shown in Table 3, which gives absolute and percentage values for the measurements of BMI, AC, TST and AMC in their categories, by nutritional state. No statistically significant association was found between any of the nutritional parameters and reactional state.

Figure 1 shows the percentage distribution of leprosy reaction by BMI category.

\section{Discussion}

One limiting factor in this study was follow-up time, because leprosy reaction can occur up to 5 years after treatment 20 . Nonetheless, in that period, we did manage to attain the expected number of patients with reaction, which made it possible to conduct the study.

The study found a frequency of leprosy reaction in patients with the disease compatible with the findings in the scientific literature 6,7 , reinforcing the need for identification and early treatment of these complications and for personnel at primary health clinics trained to dispense such care, which could reduce the physical disabilities resulting from reactions that cause suffering to patients and health care teams.

The concentration of cases of leprosy in the adult age groups identified in this study has also been noted in other studies $6,21,22$, and is 
Table 1

Distribution of patients attending health clinics in Greater Vitória, Espírito Santo State, Brazil, from January to December 2009, by socio-demographic characteristics and frequency of leprosy reaction.

\begin{tabular}{|c|c|c|c|c|c|}
\hline \multirow[t]{2}{*}{ Variable/Category } & \multicolumn{2}{|c|}{ Reaction } & \multicolumn{2}{|c|}{ No reaction } & \multirow[t]{2}{*}{ p-value } \\
\hline & $\mathrm{n}$ & $\%$ & $\mathrm{n}$ & $\%$ & \\
\hline \multicolumn{6}{|l|}{ Sex } \\
\hline Female & 29 & 52.7 & 49 & 51.0 & 0.8419 \\
\hline Male & 26 & 47.3 & 47 & 49.0 & \\
\hline \multicolumn{6}{|l|}{ Age group (years) } \\
\hline $10-19$ & 13 & 23.6 & 12 & 12.5 & 0.5361 \\
\hline $20-29$ & 6 & 10.9 & 14 & 14.6 & \\
\hline $30-39$ & 10 & 18.2 & 17 & 17.7 & \\
\hline $40-49$ & 10 & 18.2 & 19 & 19.8 & \\
\hline $50-59$ & 10 & 18.2 & 17 & 17.7 & \\
\hline 60 and over & 6 & 10.9 & 17 & 17.7 & \\
\hline \multicolumn{6}{|l|}{ Years schooling } \\
\hline $0-4$ & 11 & 20.0 & 37 & 38.5 & 0.1096 \\
\hline $5-8$ & 19 & 34.5 & 28 & 29.2 & \\
\hline $9-11$ & 19 & 34.5 & 25 & 26.0 & \\
\hline $12-15$ & 3 & 5.5 & 5 & 5.2 & \\
\hline More than 15 & 3 & 5.5 & 1 & 1.0 & \\
\hline \multicolumn{6}{|c|}{ Income (minimum wages) } \\
\hline$<1$ & 7 & 12.7 & 10 & 10.4 & 0.7607 \\
\hline $1-3$ & 31 & 56.4 & 62 & 64.6 & \\
\hline $4-5$ & 13 & 23.6 & 17 & 17.7 & \\
\hline$>5$ & 4 & 7.3 & 7 & 7.3 & \\
\hline
\end{tabular}

Table 2

Sample distribution by clinical forms of leprosy and frequency of leprosy reaction in patients at health clinics in Greater Vitória, Espírito Santo State, Brazil.

\begin{tabular}{|c|c|c|c|c|c|}
\hline \multirow[t]{2}{*}{ Variable/Category } & \multicolumn{2}{|c|}{ Reaction } & \multicolumn{2}{|c|}{ No reaction } & \multirow[t]{2}{*}{$\mathrm{p}$-value } \\
\hline & $\mathrm{n}$ & $\%$ & $\mathrm{n}$ & $\%$ & \\
\hline \multicolumn{6}{|l|}{ Clinical form } \\
\hline MHD (dimorphous) & 23 & 41.8 & 29 & 30.2 & 0.0106 \\
\hline $\mathrm{MHI}$ (indeterminate) & 0 & 0.0 & 9 & 9.4 & \\
\hline MHT (tuberculoid) & 22 & 40.0 & 47 & 49.0 & \\
\hline MHV (Virchowian) & 10 & 18.2 & 11 & 11.5 & \\
\hline \multicolumn{6}{|c|}{ MoH operational classification } \\
\hline MB (multibacillary) & 36 & 65.5 & 43 & 44.8 & 0.0144 \\
\hline PB (paucibacillary) & 19 & 34.5 & 53 & 55.2 & \\
\hline \multicolumn{6}{|l|}{ Smear } \\
\hline Negative & 41 & 74.5 & 80 & 87.9 & 0.0378 \\
\hline Positive & 14 & 25.5 & 11 & 12.1 & \\
\hline
\end{tabular}


Sample distribution by nutritional assessment in categories of body mass index (BMI), arm circumference (AC), triceps skinfold test (TST) and arm muscle circumference (AMC) and frequency of leprosy reaction in patients in treatment at health clinics in Greater Vitória, Espírito Santo State, Brazil.

\begin{tabular}{|c|c|c|c|c|c|}
\hline \multirow[t]{2}{*}{ Variable/Category } & \multicolumn{2}{|c|}{ Reaction } & \multicolumn{2}{|c|}{ No reaction } & \multirow[t]{2}{*}{$p$-value } \\
\hline & $\mathrm{n}$ & $\%$ & $\mathrm{n}$ & $\%$ & \\
\hline \multicolumn{6}{|l|}{ BMI } \\
\hline Underweight & 2 & 3.6 & 6 & 6.3 & 0.2408 \\
\hline Eutrophic & 30 & 54.5 & 44 & 45.8 & \\
\hline Overweight & 14 & 25.5 & 37 & 38.5 & \\
\hline Obese & 9 & 16.4 & 9 & 9.4 & \\
\hline \multicolumn{6}{|l|}{$A C$} \\
\hline Underweight & 12 & 21.8 & 24 & 25.0 & 0.4103 \\
\hline Eutrophic & 37 & 67.3 & 55 & 57.3 & \\
\hline Overweight/Obese & 6 & 10.9 & 17 & 17.7 & \\
\hline \multicolumn{6}{|l|}{ TST } \\
\hline Underweight & 15 & 27.3 & 41 & 42.7 & 0.1383 \\
\hline Eutrophic & 17 & 30.9 & 20 & 20.8 & \\
\hline Overweight/Obese & 23 & 41.8 & 35 & 36.5 & \\
\hline \multicolumn{6}{|l|}{ AMC } \\
\hline Underweight & 18 & 32.7 & 30 & 31.3 & 0.8512 \\
\hline Eutrophic & 37 & 67.3 & 66 & 68.8 & \\
\hline
\end{tabular}

Figure 1

Percentage distribution of leprosy reaction in body mass index (BMI) categories.

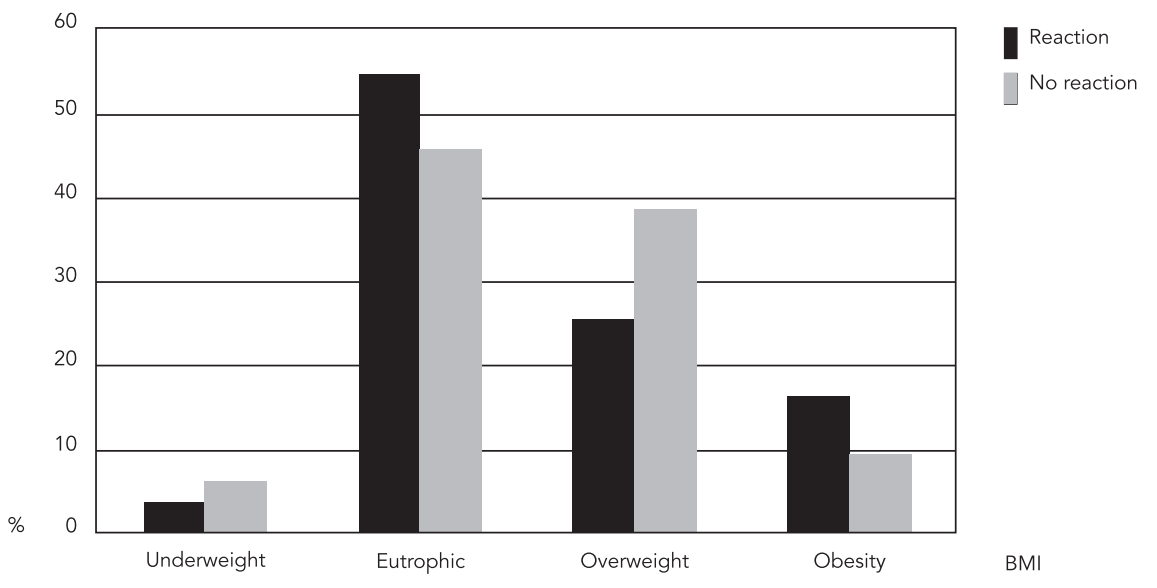


explained by the adults' more active life, which exposes them more to the bacillus 6 , and by leprosy's long incubation period, which favors its appearance at this stage of life.

The study found higher reaction frequencies among patients with positive smear test, corroborating the findings of other authors 16,21, and reinforcing the relationship of leprosy reaction with the quantity of bacilli and high bacteriological indices 9,22. Reactions appeared in both multibacillary and paucibacillary patients, but the highest frequencies were observed among the former ( $p=0.0023$ ). In MB - mainly Virchowian - patients, there are important risk factors for the development of reactions, particularly type- 2 reactions 9,22 . Such reactions can occur at any point in the evolution of leprosy, especially during specific treatment, which leads to the death of the bacillus and massive liberation of mycobacterial antigens and, consequently, to the formation of the immunocomplexes involved in their physiopathology 23.

A study performed with this same sample, using the BMI method, reported nutritional state among leprosy patients as $48.7 \%$ eutrophic and $5.3 \%$ under-nourished. Meanwhile, $34.2 \%$ were overweight and $11.8 \%$, obese 13 .

The finding here of overweight by BMI measurement category $(41.9 \%)$ coincides with the household survey conducted by the Ministry of Health in 16 of Brazil's 27 state capitals, demonstrating the nutritional transition there, and including Vitória as one of the state capitals in the southeast region with high prevalence of overweight, principally among individuals with less schooling 24 .

This study demonstrated that in the relationship between nutritional state and the occurrence of leprosy reaction, when evaluated by TST, leprosy reaction was absent more often in the underweight group, pointing to a tendency for this group to be protected from reaction. This result was found with a close to $10 \%$ significance $(\mathrm{p}=0.0906)$. The organization of an inflammatory reaction involves recruiting inflammatory cells and substances that communicate among the cells (cytokines), which calls for a balanced nutritional state (proteins, glycides, lipids). In that light, an underweight patient can probably be expected not to be properly equipped to present an immunological response, which could hinder the triggering of a leprosy reaction. To date, the authors have identified no scientific studies that associate nutritional state with leprosy reaction.

Early clinical identification of reactional episodes yields major benefits for those undergoing treatment for leprosy. That kind of precaution increases the likelihood of immediate and appropriate therapeutic intervention to prevent the development of physical disabilities and sequelae, which both stigmatize users with leprosy, and complicate their lives. However, patient followup is often difficult for lack of trained personnel to offer such care in evaluating and controlling leprosy reaction.

\section{Conclusion}

In this study, $36.4 \%$ of the patients presented with leprosy reaction, which was more frequent among the multibacillary patients, correlating with positive smear test.

The study showed no association between nutritional state and leprosy reaction. However, absence of reaction was greater in the underweight group, suggesting a tendency for this group to be protected from the reaction $(\mathrm{p}=0.0906)$.

There is a need for further studies, with larger numbers of patients presenting leprosy reaction episodes, with a view to verifying the findings. Another important requirement to be met is to conduct studies with longer observation periods, given the 5-year timeframe for the reaction to appear. 


\section{Resumo}

A hanseníase pode apresentar processos inflamatórios agudos/subagudos (reações hansênicas). Os objetivos foram caracterizar os estados reacionais de pacientes de Unidades de Saúde da Grande Vitória (Espírito Santo, Brasil) e associá-los aos fatores sociodemográficos e a variáveis clínicas/nutricionais. Estudo longitudinal, de monitoramento de portadores de hanseníase acompanhados até o aparecimento da reação hansênica ou até 6 meses iniciais da poliquimioterapia, de janeiro a dezembro de 2009. Participaram 151 pacientes, sendo 78 (51,7\%) femininos; 48 (31,8\%) estudaram de cinco a oito anos; 93 (61,6\%) trabalhavam e ganhavam de um a três salários mínimos; 55 (36,4\%) apresentaram reação hansênica, sem associação estatística às características socioeconômicas nem ao estado nutricional. Porém, a ausência de reação foi maior no grupo baixo peso, sugerindo neste grupo tendência na proteção da reação $(p=0,0906)$. No estudo não houve associação do estado nutricional com a reação hansênica.

Hanseníase; Inquéritos Nutricionais; Índice de Massa Corporal

\section{Contributors}

R. M. N. Montenegro contributed to the planning, literature review, data collection, discussion, and drafting of the article. E. Zandonade contributed to planning, statistical analysis, discussion, and drafting of the article. M. C. B. Molina and L. M. Diniz participated in the discussion and in review of the article.

\section{References}

1. Araújo MG. Leprosy in Brazil. Rev Soc Bras Med Trop 2003; 36:373-82.

2. Harry L, Odom RB, James WD, Goldschmidt H, Crekin RC. Doenças da pele de Andrews: dermatologia clínica. $8^{\text {th }}$ Ed. São Paulo: Editora Manole; 1994.

3. Talhari S, Neves RG, Penna GO, Oliveira MLW. Hanseníase: dermatologia tropical. $4^{\text {th }}$ Ed. Manaus: Tropical; 2006.

4. Nery JAC, Sales AM, Illarramendi X, Dupre NC, Jar$\operatorname{dim}$ MR, Machado AM. Contribuição ao diagnóstico e manejo dos estados reacionais: uma abordagem prática. An Bras Dermatol 2006; 81:367-75.

5. Amato Neto V, Baldy JLS. Doenças transmissíveis. São Paulo: Sarvier; 1989.

6. Nery JAC. Reação na hanseníase: uma descrição epidemiológica [Masters Thesis]. Niterói: Universidade Federal Fluminense; 1995.

7. Hastings RC. Leprosy: medicine in the tropics. New York: Churchill Livingstone; 1985.
8. Departamento de Atenção Básica, Secretaria de Políticas, Ministério da Saúde. Guia para o controle da Hanseníase. Brasília: Ministério da Saúde; 2002.

9. Manandhar R, Lemaster JW, Roche P. Risk factors for erythema nodosum leprosum. Int J Lepr 1999; (67):270-8.

10. Kac G, Sichieri R Gigante DP. Epidemiologia nutricional. In: Kac G, Sichieri R Gigante DP, editores. Introdução à epidemiologia. São Paulo: Editora Atheneu; 2007. p. 23-7.

11. Garcia ICO. Avaliação nutricional e caracterização sócio-demográfica de portadores de hanseníase [Masters Thesis]. São Paulo: Universidade de São Paulo; 2006.

12. Canicoba M, Feldman N, Lipovetzky S, Moyano O. Evaluación del estado nutricional de pacientes en un hospital con lepra en Argentina. Nutr Hosp 2007; 22:377-81. 
13. Montenegro RMN, Molina MDC, Moreira M, Zandonade E. Avaliação nutricional e alimentar de pacientes portadores de hanseníase. Rev Soc Bras Med Trop 2011; 44:228-31.

14. Diffey B, Vaz M, Soares MJ, Jacob AJ, Piers LS. The effect of leprosy-induced deformity on the nutritional status of index cases and their household members in rural South India: a socio-economic perspective. Eur J Clin Nutr 2000; 54:643-9.

15. Baialardi KS. O estigma da hanseníase: relato de uma experiência em grupo com pessoas portadoras. Hansenol Int 2007; 32:27-36.

16. Ventura KG. Estudo das reações hansênicas durante a poliquimioterapia em unidades de saúde da região metropolitana da Grande Vitória [Masters Thesis]. Vitória: Curso de Mestrado em Doenças Infecciosas, Universidade Federal do Espírito Santo; 2006.

17. Secretaria de Saúde do Espírito Santo/GEVES. Relatório de atividades do Programa Estadual de Controle de Hanseníase. Vitória: Secretaria de Saúde do Espírito Santo; 2007.

18. Organização Mundial da Saúde. Unidade guia para eliminar a hanseníase como um problema de saúde pública. Genebra: Organização Mundial da Saúde; 1995.

19. Frisancho AR. New norms of upper limb fat and muscle areas for assessment of nutritional status. Am J Clin Nutr 1981; 34:2540-5.
20. Sociedade Brasileira de Hansenologia/Sociedade Brasileira de Dermatologia. Projeto diretrizes. Hanseníase: episódios reacionais. Ribeirão Preto: Sociedade Brasileira de Hansenologia; 2003.

21. Gallo MEN, Nery JAC, Albuquerque ECA, Sigmorelli M, Silva Filho VF. Hanseníase multibacilar: índices baciloscópicos e viabilidade do M. leprae após 24 doses da PQT/OMS. An Bras Dermatol 2000; 75:291-7.

22. Saunderson P, Gebre S, Byass P. Enreactions and impairments in the multibacillary cases of the AMFES cohort in central Ethiopia: incidence and risk factors. Lepr Rev 2000; (71):318-24.

22. Silva SF, Griep RH. Reação hansênica em pacientes portadores de hanseníase em centros de saúde da Área de Planejamento do Município do Rio de Janeiro. Hansen Int 2007; 32:155-62.

23. Gillis TP, Krahehbuhl JL. Global elimination of leprosy. Rev Med Microbiol 1998; (9):39-48.

24. Instituto Nacional de Câncer. Inquérito domiciliar sobre comportamentos de risco e morbidade referida de doenças e agravos não transmissíveis: Brasil, 15 capitais e Distrito Federal, 2002-2003. Rio de Janeiro: Instituto Nacional de Câncer; 2004.

Submitted on 02/Apr/2011

Final version resubmitted on 22/Jun/2011 Approved on 19/Aug/2011 